\title{
The Association Between Breast Cancer and Thyroid Function: From Birth to Death
}

\author{
AmirAli Moodi Ghalibaf ${ }^{1, *}$ \\ ${ }^{I}$ Student Research Committee, Faculty of Medicine, Mashhad University of \\ Medical Sciences, Mashhad, Iran \\ *Corresponding author: AmirAli Moodi Ghalibaf, Student Research Com- \\ mittee, Faculty of Medicine, Mashhad University of Medical Sciences, Floor \\ 1, No 11, 16th St, Kolahdoz Ave., Mashhad, Iran. Tel: +989357705368; Fax: \\ +985138477857; E-mail:amiralimoodi1998@gmail.com
}

DOI: $10.30699 /$ mci.5.2.445-1

Submitted: 5 November 2020

Revised: 7 December 2020

Accepted: 3 January 2021

e-Published: 17 March 2021

Keywords:

Breast Neoplasms

Thyroid Gland

Thyroid Hormones
Breast cancer $(\mathrm{BC})$ is still a common malignancy among women and is the cause of many deaths. Many factors can increase the risk of breast carcinoma and its related mortality. Among these risk factors, some epidemiological studies support the idea that thyroid hormones contribute to many body functions and thyroid regulatory pathways are related to the risk of $\mathrm{BC}$. Although some studies stated that thyroid hormones, whether at high or low levels, increase the risk of $\mathrm{BC}$, controversial evidence is investigated. The current study aimed at investigating different possible associations between thyroid function and $\mathrm{BC}$, after reviewing some general subjects on $\mathrm{BC}$, and thyroid function and hormones.

(C) 2021. Multidisciplinary Cancer Investigation

\section{INTRODUCTION}

Breast Cancer (BC) is a common cancer among women worldwide, and one of the leading causes of cancer death in many countries [1]. According to epidemiological studies, it is estimated that about 2 million women were diagnosed with BC in 2020 [2]. This multifactorial disorder with different distinct subtypes has various prognostic and therapeutic approaches depending on clinical, pathologic, and molecular features present in this malignancy [3]. Too many environmental risk factors, pathological conditions, physiological agents, and endogenous factors can cause genetic and epigenetic changes leading to uncontrolled proliferation, differentiation, apoptosis, and DNA repair in cells [2]. Family history, age at menarche and menopause, age at first pregnancy, genetic mutations, and breast density are some endogenous factors that play role in $\mathrm{BC}$ incidence; on the other hand, exogenous factors, such as oral contraceptives, lifestyle, radiation, and hormone replacement therapy, like endogenous ones, can cause $\mathrm{BC}$ [4]. The etiology of $\mathrm{BC}$ is complex and both endogenous, and exogenous factors can increase the risk of $\mathrm{BC}$ [3]. There are some epidemiological studies on the higher risk of $\mathrm{BC}$ in patients with thyroid disorders and thyroid malignancies; on the other hand, studies denying this correlation are not few [5]. Therefore, given the present disagreements, the current review study aimed at investigating the role of thyroid function and its disorders, and the possible relationship between the function of one of the major body glands and one of the most prevalent malignancies. A comprehensive search was carried out through electronic databases, including Web of Science, PubMed, Scopus, Embase, and Google Scholar, using the keywords "Breast Cancer" and "Thyroid". 
All related MeSH terms were included in the search strategy to reduce the risk of missing any related article. Studies on thyroid function and its possible role in the incidence of $\mathrm{BC}$ were entered into review.

\section{Thyroid Gland and Hormones}

The thyroid, a butterfly-shaped gland, is located in the lower part of the anterior neck, between C5 and $\mathrm{T} 1$ vertebrae, weighing approximately $15-20$ g $[6,7]$. The thyroid contains lobules consisting of follicles and $\mathrm{C}$ cells between them. This rich lymphatic network gland is the only human gland in which the hormonal products are stored extracellularly [8]. Thyroid hormones play role in the development, growth, metabolic regulation, energy expenditure, and functions of the heart and brain [9]. According to the hypothalamic-pituitarythyroid (HPT) axis, thyroid hormone synthesis and secretion depend on positive and negative feedback from this axis [10]. The first hormone in the HPT axis is thyrotropin-releasing hormone (TRH) released from hypothalamus and affects the pituitary gland. An increase in TRH causes the secretion of thyroid-stimulating hormone (TSH) from the pituitary and, in turn, TSH can mainly affect thyroid function in synthesis and releasing thyroxine (T4) and triiodothyronine (T3), the two major thyroid hormones, into the bloodstream [11]. Note that some other factors, such as adequate levels of iodine, are also required for thyroid hormone synthesis [12]. Thyroid hormones, actually T4, mostly bound to thyroxine-binding globulin (TBG) in plasma, although binding to transthyretin, albumin, unbound $\mathrm{T} 4$, and unbound $\mathrm{T} 3$ can be detected in circulation [13]. Thyroxine is the prohormone form of thyroid hormones synthesized more than triiodothyronine; although the quantity of T3 is less than T4, it is more active than T4. This peripheral conversion occurs as required in tissue [14]. Most of the effects of thyroid hormones are related to T3; this active form of thyroid hormones can increase cardiac output, heart rate, ventilation rate, basal metabolic rate, catabolism of proteins and carbohydrates involved in brain development, cognitive functions, immune system modulation, female endometrium thickness, play roles in pregnancy and fetal development and potentiate the effects of catecholamines, etc. [15-19]. Many parameters can be measured to investigate the function of the thyroid gland; free $\mathrm{T} 3$ and $\mathrm{T} 4$ show the hormone activity in the body, total T3 and T4 reflecting the amount of hormone bound to TBG, and TSH level. Nuclear scan and sonography can be helpful to detect some malignancies. Moreover, advanced techniques and fetal hormone testing can be used to detect some disorders prenatally [20-23] (Figure 1).

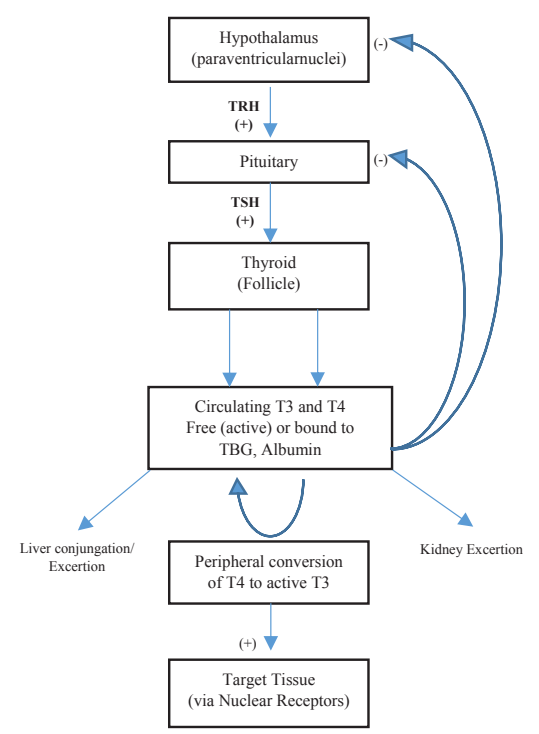

Figure 1: The Flowchart of Thyroid Hormones Regulation [2]

The thyroid releasing hormone (TRH) is synthesized and stored in the hypothalamus. TRH stimulates the secretion of thyroid-stimulating hormone (TSH) from anterior cells of the pituitary. The binding of TSH to its receptors in thyroid cells stimulate thyroid hormones synthesis. T4 is the inactive form of thyroid hormones. Peripheral conversion of T4 to T3 leads to the activation of the hormone and the active form, T3, affects the target tissue. The regulation and elimination pathways of thyroid hormones are also demonstrated in Figure [1].

Similar to many other hormones, hypersecretion or deficiency of thyroid hormones can cause disorders; hyperthyroidism, Graves' disease, hypothyroidism, and Hashimoto thyroiditis are the major ones [24]. In hyperthyroidism and Graves' disease (an autoimmune disease), thyroid hormones, such as free thyroxine, free triiodothyronine, or both, are hypersecreted in circulation. This high serum level of thyroid hormones can cause osteoporosis, atrial fibrillation, hypertension, and congestive heart failure [25-27]. On the other hand, hypothyroidism and Hashimoto thyroiditis are conditions in which thyroid hormone levels in circulation decrease. In hypothyroidism condition, sensitivity to the actions 
of narcotics, barbiturates, and tranquilizers are likely; increased susceptibility to infectious diseases, megacolon, psychosis with paranoia, infertility, and myxedema are some complications [26].

\section{Thyroid Hormones Signaling Pathways}

Recent studies indicate that thyroid hormones can trigger two different signaling pathways, genomic and non-genomic.

\section{Genomic pathway of thyroid hormones signaling}

Free circulating thyroid hormones can activate signaling pathways and transcriptional factors by binding to their specific nuclear receptors [28]. In detail, thyroid hormone receptors include alpha and beta types (TR $\alpha$ and TR $\beta$ ), containing several domains and other functional and regulatory parts [29]. There are four major isoforms for the thyroid hormone receptors, TR $\alpha 1$, TR $\alpha 2$, TR $\beta 1$, and TR $\beta 2$ encoded by their specific genes. TR $\alpha 1$ and TR $\alpha 2$ are expressed by the c-erbA $\alpha$ gene located on chromosome 17, and these receptors can be mostly detected in the kidney, skeletal muscles, lungs, heart, testes, and brain. On the other hand, the $\mathrm{c}-\operatorname{erbA} \beta$ gene located on chromosome 3 encodes TR $\beta 1$ and TR $\beta 2$. TR $\beta 1$ expression is significant in the brain, thyroid, liver, kidney, and breast, while the TR $\beta 2$ isoform is specifically expressed in the anterior pituitary, hypothalamus, and non-developed brain [30-33]. Studies indicate that three isoforms of the thyroid hormone receptors, TR $\alpha 1, \mathrm{TR} \alpha 2$, and TR $\beta 1$, are overexpressed in various tissue but not in the liver [34]. Although several studies demonstrated the lower expression of TR $\beta 1$ in adenomas and cancers, it is observed that abnormal expression or mutation of TR $\beta 1$ promotes carcinogenesis. It is interesting that in some studies, the increase in BRCA1-associated BC surveillance was performed when the expression of TR $\beta 1$ increased $[35,36]$. The binding of $\mathrm{T} 3$ with the nuclear receptors induces conformational changes in the receptor, and this process finally leads to transcription of the gene
[37]. The effects of thyroid hormones are mediated by the phosphatidylinositol 3-kinase (PI3K), which is a lipid kinase that can phosphorylate phosphatidylinositol (4, 5)-bisphosphate and produce phosphatidylinositol $(3,4,5)$-trisphosphate (PIP3). This process aims to initiate a signaling cascade and mediate the thyroid hormone effect [38]. In the current cascade, PI3K upregulates the effector and AKT to phosphorylate proteins and changes the gene expression. PI3K-AKT promotes cell survival and proliferation and can cause tumorigenesis [39]. In another pathway, T3 can induce the expression of the TGF $\alpha$ and TGF $\beta$ in estrogen-positive BC [40]. Also, in aggressive triple-negative BC, this hormone can increase the Warburg effect, which is a hallmark of cell transformation [41]. In another way, the T3 inhibits the STAT5 signaling pathway. It can associate with TR $\beta 1$ as a tumor suppressor protein to inhibit mammary hyperplasia development [42]. Also, the overexpression of the $\mathrm{T} 1$ gene is seen in breast adenocarcinoma, which is induced by mitogens, serum, specific oncogenes, and cytokines, but this gene is suppressed in high $\mathrm{T} 3$ concentrations and, therefore, leads to reduced BC cell proliferation [43]. The other thyroid hormone, T4, induces serine phosphorylation of ER $\alpha$ and leads to transcription activation [44]. Recent studies indicated that T4 could stimulate PD-L1 gene expression and increase in PD-L1 protein can cause defense against immune destruction in BC cells [45] (Table 1).

\section{Non-genomic pathway of thyroid hormones sig- naling}

According to some primary studies, thyroid hormones can act through mitochondria and cytoskeleton, besides the nuclear receptors [46]. These rapid actions that are not exerted through genes are called "non-genomic" [47]. The integrin family constitutes structural proteins with 24 isoforms. These proteins mediate cell-cell and cell-extracellular matrix (ECM) interactions. The

\begin{tabular}{lcccc}
\hline \multicolumn{4}{l}{ Table 1: The Summary of Genomic and Non-genomic Signaling Pathways of Thyroid Hormones } & \\
\hline TH & Receptor & Pathway & Action & Signaling Pathway \\
\hline T3 & TR $\beta$ & T1 gene downregulation & proliferation decrease & genomic \\
T3 & TR $\beta$ & STAT5 signaling inhibition & development decrease & non-genomic \\
\hline
\end{tabular}

a Abbreviations: ERK, extracellular signal-regulated kinase; MAPK, mitogen-activated protein kinase; STAT5, signal transducer and activator of transcription 5; T3, triiodothyronine; T4, thyroxine; TH, thyroid hormone; TR $\beta$, thyroid hormone receptor-beta 
$\alpha v \beta 3$ is one of the integrin isoforms that binding to thyroid hormones near it can cause activation of intracellular signaling through ECM proteins, such as osteopontin, fibronectin, and vitronectin [48, 49]. Based on the interaction of $\alpha v \beta 3$ with thyroid hormones, mitogen-activated protein kinase/ extracellular signal-regulated kinase (MAPK/ ERK 1/2) pathways are activated to regulate multiple cellular physiological processes [47]. This pathway can occur in breast cells; in another word, $\mathrm{TH}$ promotes $\mathrm{BC}$ cell proliferation by activation of the MAPK/ERK $1 / 2$ pathway via affecting estrogen receptors [44] (Table 1). Studies indicated that in ER-negative $\mathrm{BC}$ cells, the $\alpha \mathrm{v} \beta 3$ inhibitor, tetraiodothyroacetic acid (tetrac), prevents the initiation of thyroid hormones cellular action [45].

\section{Thyroid Hormones in Different Life Cycles of Women}

\section{Puberty and menstruation}

Since the role of thyroid hormones in normal growth, sexual development, and reproductive functions is of great importance, changes in thyroid hormones function and circulation levels occur during puberty for sexual development and body adaptation. Both hypothyroidism and hyperthyroidism can cause sexual disorders. In detail, hypothyroidism causes delayed puberty or incomplete isosexual precocity; hyperthyroidism, in a long time, may cause menstrual dysfunction and infertility. However, some of these complications are related to both hypoand hyperthyroidism [50, 51]. Thyroid function is associated with menstruation, and abnormal uterine bleeding, abnormal sexual development, delayed puberty, hirsutism, infertility, and recurrent pregnancy loss might be the outcomes of thyroid dysfunction. In hyperthyroidism, oligomenorrhea, amenorrhea, and anovulatory cycles may occur. On the contrary, polymenorrhea and galactorrhea are common in hypothyroidism. It is crucial to emphasize that thyroid dysfunction is one of the most probable causes of infertility [52-55].

\section{Thyroid hormones and pregnancy}

Definite physiological changes in the maternal thyroid gland are observed during pregnancy. Thyroid hyperplasia and an increase in vascularisation of the gland are among such changes. Due to these conditions, thyroid hormones and related circulatory factors increase. Consequently, iodine intake is increased [56, 57]. Hypothyroidism is prevalent during pregnancy. Maternal hypothyroidism, which is more common as Hashimoto thyroiditis, is associated with an increased risk of miscarriage and preterm delivery, decreased IQ level, and birth weight of offspring [58]. On the other hand, hyperthyroidism is less common than hypothyroidism, but such conditions- i.e. Graves' disease, can cause stillbirth, preterm delivery, intrauterine growth restriction, preeclampsia, and heart failure [59].

\section{Thyroid hormones and postmenopausal women}

A situation in which there is a year without menses in a woman who had menses before is called menopause. Menopause occurs in the 40s and 50s decade of women's lives, and women often experience complications, such as fatigue, moodiness, irregular periods, sleep problems, loss of sex drive, and weight gain $[60,61]$. Due to the physiological and hormonal changes after menopause, degenerated thyroid epithelium and atrophic gland are observed [62]. Therefore, these various changes make hypothyroidism more probable in postmenopause women than hyperthyroidism. These changes also affect other metabolic aspects and functions of the body, which may lead to dangerous conditions, such as the increased risk of atrial fibrillation, coronary heart disease, bone loss, etc. [62-64].

Taking a Glance at the Role of Thyroid Function and Thyroid Hormones Status in Breast Cancer

Many studies were performed to determine the relationship between $\mathrm{BC}$ and thyroid function; however, this correlation is uncertain. The cohort of 142,216 women showed that women with hyperthyroid are at higher risk of $\mathrm{BC}$ than those with hypothyroid [65]. Another cohort of 75,076 women aged 20-89 years indicated that the risk of $\mathrm{BC}$ and mortality due to this malignancy is related to thyroid function. Also, the incidence of $\mathrm{BC}$ in women with hyperthyroidism was more than the ones with hypothyroid. Moreover, the mortality due to breast carcinoma was observed in women over 60 years old with hyperthyroid disordermore than those with hypothyroiddisorder [66]. To determine the mechanisms of this phenomenon, many studies were conducted, which had controversial findings. The expression of hypoxia-inducing factor 1 alpha (HIF1A), a protein that regulates the transcription 
of cellular and developmental responses to hypoxia, is related to several cancers, including mammary carcinogenesis [67, 68]. Transforming growth factor-alpha (TGFA) is a member of the epidermal growth factor family that stimulates mitosis and plays a role in cell proliferation, differentiation, and development [67, 69]. Both HIF1A and TGFA can induce angiogenesis. T3 can stimulate the expression of these genes in the MCF7 BC cell line by activating the PI3K pathway [67]. Besides, MCF7 cell proliferation is promoted due to an increase in the activity of ER expression induced by T3 and T47D cells as an estrogen-responsive human ductal carcinoma cell lines, expressing detectable levels of ER. Note that T47D proliferation is regulated by T3 via increasing P53 levels [70, 71]. Although the risk of hypothyroidism is more common in postmenopausal women, controversial results were observed in the relationship between the risk of BC in postmenopausal women and thyroid function. Some studies determined that the lower levels of thyroid hormones decrease the risk of $\mathrm{BC}$, but some others mentioned that both higher and lower serum levels of thyroid hormones could increase the risk of $\mathrm{BC}$ [72-76]. The thyroid hormone receptor (TR) is a nuclear receptor activated via thyroid hormone binding. These receptors, with non-genomic effects, act as the second messenger after activation. TRs can affect several metabolic aspects of the cells and their function is necessary for the development of many tissue [77, 78]. One of the other factors related to thyroid function that may influence the risk of BC is TR. TRs can also be associated with BRCA1. The two isoforms of TR may play different roles in BC development and progression; TR $\beta$ is a tumor suppressor, and TR $\alpha$ has the opposite function. The dysfunction of TR $\beta$ can occur during genetic mutations and the regulatory mechanisms mediated by microRNA. Some regions, such as Mkar, Mdbs, and AM, in the C-terminal of TR $\beta 1$ exhibit oncogenic activities, which can cause cell proliferation and suppression of differentiation and apoptosis. Although many studies highlighted the role of TRs in BC, several other studies did not find any relationships, and the exact role of TRs in breast carcinogenesis is unclear [36, 79-81]. Several studies demonstrated the association between autoimmune antibodies, including thyroid peroxidase antibodies (TPOAbs) and thyroglobulin antibodies (TgAbs), and $\mathrm{BC}$; the higher the level of autoimmune antibodies, a situation similar to Grave disease, the more the risk of $\mathrm{BC}[82,83]$.

\section{CONCLUSION}

$\mathrm{BC}$ is a highly prevalent malignancy among women worldwide. Many factors and risk factors can underlie breast carcinoma; moreover, the prognosis and progression of mammary carcinoma, regardless of its type and subtype, can be affected by many endogenous or exogenous factors. The thyroid, an endocrine gland, formation initiates at 3-4 weeks of gestation, and the blood level of two main hormones of this gland is detectable on various timelines; in other words, T4 is detectable at 18-20 weeks and T3 at 10 weeks onward. Thyroid hormone production occurs in thyroid follicles in processes that need iodine, special proteins, and other factors essential for the production and transportation of the hormones. The inactive form of T4 is transformed into the active form, T3, in the target tissue. T3 involves in many functions of the body and has metabolic and developmental roles. The HPT pathway is the main regulator pathway for thyroid functions. According to different periods of life and multi-situations that causing various diseases, the thyroid function and the blood levels of its hormones alter; either increase (hyperthyroidism) or decrease (hypothyroidism). Some studies determined that thyroid function is associated with $\mathrm{BC}$ via genomic and non-genomic activities of the thyroid gland, thyroid hormones, thyroid receptors, and related genes. Although many studies support the idea that higher levels of thyroid hormones increase the risk of breast malignancies, studies highlighting the inverse hypothesis are not few. The controversial results of the reviewed studies indicate the necessity for further studies in this field in order to clarify the association.

\section{ACKNOWLEDGMENTS}

None declared.

\section{CONFLICT OF INTEREST}

The authors declared no conflict of interest.

\section{ETHICS APPROVAL}

Not Applicable. 


\section{REFERENCES}

1. Waks AG, Winer EP. Breast cancer treatment: a review. JAMA. 2019;321(3):288-300. DOI: 10.1001/ jama.2018.19323 PMID: 30667505.

2. De Sibio MT, de Oliveira M, Moretto FCF, Olimpio RMC, Conde SJ, Luvizon AC, et al. Triiodothyronine and breast cancer. World J Clin Oncol. 2014;5(3):503. DOI: 10.5306/ wjco.v5.i3.503 PMID: 25114863.

3. Ajayi O, Charles-Davies M, Anetor J, Ademola A. Pituitary, Gonadal, Thyroid Hormones and Endocrine Disruptors in Pre and Postmenopausal Nigerian Women with ER-, PR-and HER-2-Positive and Negative Breast Cancers. Med Sci. 2018;6(2):37. DOI: 10.3390/medsci6020037 PMID: 29783652.

4. McPherson K, Steel C, Dixon J. Breast cancer-epidemiology, risk factors, and genetics. BMJ. 2000;321(7261):6248. DOI: $10.1136 /$ bmj.321.7261.624 PMID: 10977847.

5. Turken O, NarIn Y, DemIrbas S, Onde ME, Sayan O, KandemIr EG, et al. Breast cancer in association with thyroid disorders. Breast Cancer Res. 2003;5(5):R110. DOI: 10.1186/bcr609 PMID: 12927040.

6. Ganong WF. Review of Medical Physiology. United Kingdom: McGraw-Hill; 2005.

7. Stathatos N. Anatomy and physiology of the thyroid gland. The Thyroid and Its Diseases: Springer; 2019. p. 3-12. DOI: 10.1007/978-3-319-72102-6_1.

8. Benvenga S, Tuccari G, Ieni A, Vita R. Thyroid Gland: Anatomy and Physiology囚. In: Huhtaniemi I, Martini L, editors. Encyclopedia of Endocrine Diseases (Second Edition). Oxford: Academic Press; 2018. p. 382-90. DOI: 10.1016/B978-0-12-801238-3.96022-7.

9. Soundarrajan M, Kopp PA. Thyroid Hormone Biosynthesis and Physiology. Thyroid Dis Reprod: Springer; 2019. p. 1-17. DOI: 10.1007/978-3-319-99079-8_1.

10. Zoeller RT, Tan SW, Tyl RW. General background on the hypothalamic-pituitary-thyroid (HPT) axis. Crit Rev Toxicol. 2007;37(1-2):11-53. DOI: 10.1080/10408440601123446 PMID: 17364704.

11. Pescovitz OH, Eugster EA. Pediatric endocrinology: mechanisms, manifestations, and management. 1st ed. United Kingdom: Lippincott Williams \& Wilkins; 2004. 839 p.

12. Ahad F, Ganie SA. Iodine, iodine metabolism and iodine deficiency disorders revisited. Indian J Endocrinol Metab. 2010;14(1):13. PMID: 21448409.

13. Visser TJ. Thyroid hormone transporters and resistance. Endocr Dev. 2013;24:1-10. DOI: 10.1159/000343695 PMID: 23392090.

14. Kansagra SM, McCudden CR, Willis MS. The challenges and complexities of thyroid hormone replacement. Lab Med. 2010;41(6):338-48. DOI: 10.1309/LMB39TH2FZGNDGIM.

15. De Vito P, Incerpi S, Pedersen JZ, Luly P, Davis FB, Davis PJ. Thyroid hormones as modulators of immune activities at the cellular level. Thyroid. 2011;21(8):879-90. DOI: 10.1089/thy.2010.0429 PMID: 21745103.

16. Panesar NS, Li CY, Rogers MS. Reference intervals for thyroid hormones in pregnant Chinese women. An- nals of clinical biochemistry. 2001;38(4):329-32. DOI: 10.1258/0004563011900830 PMID: 11471873.

17. Bernal J. Thyroid Hormones and Brain Development. Vitam Horm. 2005;71:95-122. DOI: 10.1016/S00836729(05)71004-9 PMID: 16112266.

18. Rovet JF. The role of thyroid hormones for brain development and cognitive function. Paediatric Thyroidology. 26: Karger Publishers; 2014. p. 26-43. DOI: 10.1159/000363153.

19. Gelfand RA, Hutchinson-Williams KA, Bonde AA, Castellino P, Sherwin RS. Catabolic effects of thyroid hormone excess: the contribution of adrenergic activity to hypermetabolism and protein breakdown. Metabolism. 1987;36(6):562-9. DOI: 10.1016/0026-0495(87)90168-5 PMID: 2884552.

20. Mansi L, Moncayo R, Cuccurullo V, Dottorini ME, Rambaldi PF. Nuclear medicine in diagnosis, staging and follow-up of thyroid cancer. Q J Nucl Med Mol Imaging. 2004;48(2):82-95. PMID: 15243406.

21. Jain N, Brahmbhatt P, Chaudhuri CR, Singhal A. Ultrasonography of Thyroid Lesions with Clinicopathological Correlation. Int J Res Rev. 2020;7(1):142-58.

22. Polak M, Luton D. Fetal thyroidology. Best Pract Res Clin Endocrinol Metab. 2014;28(2):161-73. DOI: 10.1016/j. beem.2013.04.013 PMID: 24629859.

23. Stockigt JR. Case finding and screening strategies for thyroid dysfunction. Clinica chimica acta. 2002;315(1-2):11124. DOI: 10.1016/S0009-8981(01)00715-X.

24. Grimm D. Cell and Molecular Biology of Thyroid Disorders. Int J Mol Sci. 2019;20(12):2895. DOI: 10.3390/ ijms20122895 PMID: 31200596.

25. Taylor PN, Albrecht D, Scholz A, Gutierrez-Buey G, Lazarus JH, Dayan CM, et al. Global epidemiology of hyperthyroidism and hypothyroidism. Nat Rev Endocrinol. 2018;14(5):301. DOI: 10.1038/nrendo.2018.18 PMID: 29569622.

26. Little JW. Thyroid disorders. Part II: hypothyroidism and thyroiditis. Oral Surg Oral Med Oral Pathol Oral Radiol Endod. 2006;102(2):148-53. DOI: 10.1016/j. tripleo.2005.05.070 PMID: 16876054.

27. Little JW. Thyroid disorders. Part I: hyperthyroidism. Oral Surg Oral Med Oral Pathol Oral Radiol Endod. 2006;101(3):276-84. DOI: 10.1016/j.tripleo.2005.05.069 PMID: 16504858 .

28. Aranda A, Pascual A. Nuclear hormone receptors and gene expression. Physiol Rev. 2001. DOI: 10.1152/physrev.2001.81.3.1269 PMID: 11427696.

29. Cheng S-y. Multiple mechanisms for regulation of the transcriptional activity of thyroid hormone receptors. Rev Endocr Metab Disord. 2000;1(1-2):9-18. DOI: 10.1023/a:1010052101214 PMID: 11704997.

30. Shao D, Lazar MA. Modulating nuclear receptor function: may the phos be with you. J Clin Invest. 1999;103(12):16178. DOI: 10.1172/JCI7421 PMID: 10377165.

31. Yen PM. Physiological and molecular basis of thyroid hormone action. Physiol Rev. 2001;81(3):1097-142. DOI: 10.1152/physrev.2001.81.3.1097 PMID: 11427693. 
32. Pascual A, Aranda A. Thyroid hormone receptors, cell growth and differentiation. Biochim Biophys Acta. 2013;1830(7):3908-16. DOI: 10.1016/j. bbagen.2012.03.012 PMID: 22484490.

33. Williams GR. Cloning and characterization of two novel thyroid hormone receptor $\beta$ isoforms. Molecular and cellular biology. 2000;20(22):8329-42. DOI: 10.1128/ MCB.20.22.8329-8342.2000 PMID: 11046130.

34. Mitsuhashi T, Tennyson GE, Nikodem VM. Alternative splicing generates messages encoding rat c-erbA proteins that do not bind thyroid hormone. Proc Natl Acad Sci. 1988;85(16):5804-8. DOI: 10.1073/pnas.85.16.5804 PMID: 2901090 .

35. Park JW, Zhao L, Cheng S-Y. Inhibition of estrogen-dependent tumorigenesis by the thyroid hormone receptor $\beta$ in xenograft models. Am J Cancer Res. 2013;3(3):302. PMID: 23841029.

36. Heublein S, Mayr D, Meindl A, Angele M, Gallwas J, Jeschke U, et al. Thyroid hormone receptors predict prognosis in BRCA1 associated breast cancer in opposing ways. PloS One. 2015;10(6):e0127072. DOI: 10.1371/ journal.pone.0127072 PMID: 26029931.

37. Ayers S, Switnicki MP, Angajala A, Lammel J, Arumanayagam AS, Webb P. Genome-wide binding patterns of thyroid hormone receptor beta. PloS One. 2014;9(2):e81186. DOI: 10.1371/journal.pone.0081186 PMID: 24558356.

38. Martin NP, Marron Fernandez de Velasco E, Mizuno F, Scappini EL, Gloss B, Erxleben C, et al. A rapid cytoplasmic mechanism for PI3 kinase regulation by the nuclear thyroid hormone receptor, TR $\beta$, and genetic evidence for its role in the maturation of mouse hippocampal synapses in vivo. Endocrinology. 2014;155(9):3713-24. DOI: 10.1210/en.2013-2058 PMID: 24932806.

39. Liu P, Cheng H, Roberts TM, Zhao JJ. Targeting the phosphoinositide 3-kinase pathway in cancer. Nat Rev Drug Discov. 2009;8(8):627-44. DOI: 10.1038/nrd2926 PMID: $\underline{19644473 .}$

40. Nogueira CR, Brentani MM. Triiodothyronine mimics the effects of estrogen in breast cancer cell lines. J Steroid Biochem Mol Biol. 1996;59(3-4):271-9. DOI: 10.1016/S09600760(96)00117-3 PMID: 9010319.

41. Suhane S, Ramanujan VK. Thyroid hormone differentially modulates Warburg phenotype in breast cancer cells. Biochem Biophys Res Commun. 2011;414(1):73-8. DOI: 10.1016/j.bbrc.2011.09.024 PMID: 21945435.

42. Guigon CJ, Kim DW, Willingham MC, Cheng SY. Mutation of thyroid hormone receptor- $\beta$ in mice predisposes to the development of mammary tumors. Oncogene. 2011;30(30):3381-90. DOI: 10.1038/onc.2011.50 PMID: 21399657.

43. González-Sancho JM, Figueroa A, López-Barahona M, López E, Beug H, Muñoz A. Inhibition of proliferation and expression of $\mathrm{T} 1$ and cyclin D1 genes by thyroid hormone in mammary epithelial cells. Mol Carcinog. 2002;34(1):2534. DOI: $10.1002 / \mathrm{mc} .10046$ PMID: 12112320.

44. Tang H-Y, Lin H-Y, Zhang S, Davis FB, Davis PJ. Thyroid hormone causes mitogen-activated protein kinase-de- pendent phosphorylation of the nuclear estrogen receptor. Endocrinology. 2004;145(7):3265-72. DOI: 10.1210/ en.2004-0308 PMID: 15059947.

45. Lin H-Y, Chin Y-T, Nana AW, Shih Y-J, Lai H-Y, Tang H-Y, et al. Actions of 1-thyroxine and Nano-diamino-tetrac (Nanotetrac) on PD-L1 in cancer cells. Steroids. 2016;114:5967. DOI: 10.1016/j.steroids.2016.05.006 PMID: 27221508.

46. Siegrist-Kaiser CA, Juge-Aubry C, Tranter MP, Ekenbarger DM, Leonard JL. Thyroxine-dependent modulation of actin polymerization in cultured astrocytes. A novel, extranuclear action of thyroid hormone. J Biol Chem. 1990;265(9):5296-302. DOI: 10.1016/S00219258(19)34121-3.

47. Bergh JJ, Lin H-Y, Lansing L, Mohamed SN, Davis FB, Mousa $\mathrm{S}$, et al. Integrin $\alpha \mathrm{V} \beta 3$ contains a cell surface receptor site for thyroid hormone that is linked to activation of mitogen-activated protein kinase and induction of angiogenesis. Endocrinology. 2005;146(7):2864-71. DOI: 10.1210/en.2005-0102 PMID: 15802494.

48. Plow EF, Haas TA, Zhang L, Loftus J, Smith JW. Ligand binding to integrins. J Biol Chem. 2000;275(29):21785-8. DOI: $10.1074 / \mathrm{jbc}$. R000003200 PMID: 10801897.

49. Lin H-Y, Cody V, Davis FB, Hercbergs AA, Luidens MK, Mousa SA, et al. Identification and functions of the plasma membrane receptor for thyroid hormone analogues. Discov Med. 2011;11(59):337-47. PMID: 21524387.

50. Weber G, Vigone MC, Stroppa L, Chiumello G. Thyroid function and puberty. J Pediatr Endocrinol Metab. 2003;16:253-7. PMID: 12729400.

51. Marwaha RK, Tandon N, Desai AK, Kanwar R, Sastry A, Narang A, et al. The evolution of thyroid function with puberty. Clin Endocrinol. 2012;76(6):899-904. DOI: 10.1111/j.1365-2265.2011.04305.x PMID: 22171622.

52. Koutras DA. Disturbances of menstruation in thyroid disease. Ann N Y Acad Sci. 1997;816:280-4. DOI: 10.1111/ j.1749-6632.1997.tb52152.x PMID: 9238278.

53. Sharma N, Sharma A. Thyroid profile in menstrual disorders. JK Sci. 2012;14(1):14.

54. Trokoudes KM, Skordis N, Picolos MK. Infertility and thyroid disorders. Curr Opin Obstet Gynecol. 2006;18(4):44651. DOI: 10.1097/01.gco.0000233941.89919.31 PMID: 16794427.

55. Krassas GE. Thyroid disease and female reproduction. Fertil Steril. 2000;74(6):1063-70. DOI: 10.1016/S00150282(00)01589-2 PMID: 11119728.

56. El Baba KA, Azar ST. Thyroid dysfunction in pregnancy. Int J Gen Med. 2012;5:227. DOI: 10.2147/IJGM.S27009 PMID: 22419883.

57. Leung AM. Thyroid function in pregnancy. J Trace Elem Med Biol. 2012;26(2-3):137-40. DOI: 10.1016/j. jtemb.2012.03.004 PMID: 22658718.

58. Stagnaro-Green A, Pearce E. Thyroid disorders in pregnancy. Nat Rev Endocrinol. 2012;8(11):650-8. DOI: 10.1038/ nrendo.2012.171 PMID: 23007317.

59. Nazarpour S, Tehrani FR, Simbar M, Azizi F. Thyroid dysfunction and pregnancy outcomes. Iran J Reprod Med. 2015;13(7):387. PMID: 26494985. 
60. del Ghianda S, Tonacchera M, Vitti P. Thyroid and menopause. Climacteric. 2014;17(3):225-34. DOI: 10.3109/13697137.2013.838554 PMID: 23998691.

61. Kapadia NA, Mehta N. Comparison of thyroid profile in premenopausal and postmenopausal women. Int. J. Basic Appl. Physiol. 2017;6:150-4.

62. Gietka-Czernel M. The thyroid gland in postmenopausal women: physiology and diseases. Prz Menopauzalny. 2017;16(2):33. DOI: 10.5114/pm.2017.68588 PMID: 28721126.

63. Bottiglioni F, De Aloysio D, Nicoletti G, Mauloni M, Mantuano R, Capelli M. A study of thyroid function in the preand post-menopause. Maturitas. 1983;5(2):105-14. DOI: 10.1016/0378-5122(83)90006-3 PMID: 6415363.

64. Niafar M, Pourafkari L, Aminmozaffari S, Nader ND. Association of Vitamin D Deficiency and Thyroid Function in Postmenopausal Women. Adv Pharm Bull. 2016;6(4):63944. DOI: 10.15171/apb.2016.078 PMID: 28101471.

65. Søgaard M, Farkas DK, Ehrenstein V, Jørgensen J, Dekkers OM, Sørensen HT. Hypothyroidism and hyperthyroidism and breast cancer risk: a nationwide cohort study. Eur J Endocrinol. 2016;174(4):409. DOI: 10.1530/EJE-15-0989 PMID: 26863886.

66. Journy NMY, Bernier M-O, Doody MM, Alexander BH, Linet MS, Kitahara CM. Hyperthyroidism, hypothyroidism, and cause-specific mortality in a large cohort of women. Thyroid. 2017;27(8):1001-10. DOI: 10.1089/ thy.2017.0063 PMID: 28578598.

67. Moretto FCF, De Sibio MT, Luvizon AC, Olimpio RMC, De Oliveira M, Alves CAB, et al. Triiodothyronine (T3) induces HIF1A and TGFA expression in MCF7 cells by activating PI3K. Life Sci. 2016;154:52-7. DOI: 10.1016/j. lfs.2016.04.024 PMID: 27094789.

68. Ni J, Bühler L, Stojanovic A, Arnold A, Sexl V, Cerwenka A. Abstract 4743: Inhibition of the $<$ em $>$ Hifla $</$ em $>$-mediated checkpoint refuels NK activation in cancer. Cancer Res. 2018;78(13 Supplement):4743-. DOI: 10.1158/15387445.am2018-4743.

69. Semenza GL. Molecular mechanisms mediating metastasis of hypoxic breast cancer cells. Trends Mol Med. 2012;18(9):534-43. DOI: 10.1016/j.molmed.2012.08.001 PMID: 22921864.

70. Dinda S, Sanchez A, Moudgil V. Estrogen-like effects of thyroid hormone on the regulation of tumor suppressor proteins, p53 and retinoblastoma, in breast cancer cells. Oncogene. 2002;21(5):761-8. DOI: 10.1038/sj.onc.1205136 PMID: 11850804.

71. Hall LC, Salazar EP, Kane SR, Liu N. Effects of thyroid hormones on human breast cancer cell proliferation. J Steroid Biochem Mol Biol. 2008;109(1-2):57-66. DOI: 10.1016/j.jsbmb.2007.12.008 PMID: 18328691.

72. Ortega-Olvera C, Ulloa-Aguirre A, Ángeles-Llerenas A, Mainero-Ratchelous FE, González-Acevedo CE, de Lourdes Hernández-Blanco M, et al. Thyroid hormones and breast cancer association according to menopausal status and body mass index. Breast Cancer Res. 2018;20(1):94. DOI: 10.1186/s13058-018-1017-8 PMID: 30092822.

73. Weng C-H, Okawa ER, Roberts MB, Park SK, Umbricht CB, Manson JE, et al. Breast Cancer Risk in Postmenopausal Women with Medical History of Thyroid Disorder in the Women's Health Initiative. Thyroid. 2020;30(4):51930. DOI: 10.1089/thy.2019.0426 PMID: 31918623.

74. Dobrinja C, Scomersi S, Giudici F, Vallon G, Lanzaro A, Troian M, et al. Association between benign thyroid disease and breast cancer: a single center experience. BMC Endocr Disord. 2019;19(1):1-8. DOI: 10.1186/s12902019-0426-8 PMID: 31623603.

75. Kuijpens JLP, Nyklíčtek I, Louwman MWJ, Weetman TAP, Pop VJM, Coebergh J-WW. Hypothyroidism might be related to breast cancer in post-menopausal women. Thyroid. 2005;15(11):1253-9. DOI: 10.1089/thy.2005.15.1253 PMID: 16356089 .

76. Tosovic A, Bondeson A-G, Bondeson L, Ericsson U-B, Malm J, Manjer J. Prospectively measured triiodothyronine levels are positively associated with breast cancer risk in postmenopausal women. Breast Cancer Res. 2010;12(3):R33. DOI: 10.1186/bcr2587 PMID: 20540734.

77. Flamant F, Baxter JD, Forrest D, Refetoff S, Samuels H, Scanlan TS, et al. International Union of Pharmacology. LIX. The pharmacology and classification of the nuclear receptor superfamily: thyroid hormone receptors. Pharmacol Rev. 2006;58(4):705-11. DOI: 10.1124/pr.58.4.3 PMID: 17132849 .

78. Harvey CB, Williams GR. Mechanism of thyroid hormone action. Thyroid. 2002;12(6):441-6. DOI: $\underline{10.1089 / 105072502760143791}$ PMID: 12165104.

79. Ortiga-Carvalho TM, Sidhaye AR, Wondisford FE. Thyroid hormone receptors and resistance to thyroid hormone disorders. Nat Rev Endocrinol. 2014;10(10):582. DOI: 10.1038/nrendo.2014.143 PMID: 25135573.

80. Ling Y, Ling X, Fan L, Wang Y, Li Q. Mutation analysis underlying the downregulation of the thyroid hormone receptor $\beta 1$ gene in the Chinese breast cancer population. Onco Targets Ther. 2015;8:2967. DOI: 10.2147/OTT. S93418 PMID: 26527882.

81. Park JW, Zhao L, Willingham M, Cheng S-y. Oncogenic mutations of thyroid hormone receptor $\beta$. Oncotarget. 2015;6(10):8115-31. DOI: 10.18632/oncotarget.3466 PMID: 25924236.

82. Jiskra J, Limanova Z, Barkmanova J, Smutek D, Friedmannova Z. Autoimmune thyroid diseases in women with breast cancer and colorectal cancer. Physiol Res. 2004;53(6):693702. PMID: 15588139 .

83. Gogas J, Kouskos E, Tseleni-Balafouta S, Markopoulos C, Revenas K, Gogas G, et al. Autoimmune thyroid disease in women with breast carcinoma. Eur J Surg Oncol. 2001;27(7):626-30. DOI: 10.1053/ejso.2001.1204 PMID: 11669589. 